International Journal of Child, Youth, and Family Studies (2014): 5(4.2) 718-721

\title{
INTRODUCTION TO THE SPECIAL ISSUE ON MATERIALITY IN EARLY CHILDHOOD STUDIES
}

\author{
Laurie Kocher, Veronica Pacini-Ketchabaw, and Sylvia Kind, Guest Editors
}

Acknowledgements: The editors would like to thank the Social Sciences and Humanities Research Council of Canada for their support.

Materials live in the world in multiple ways. They can evoke memories, narrate stories, invite actions, and communicate meanings. Materials and objects create meeting places. In early childhood education we gather around things to investigate, negotiate, converse, and share. Materials - a block of clay, pots of paint, a brush, a colourful wire, a translucent sheet of paper, a rectangular block beckon and draw us in. Materials are not immutable, passive, or lifeless until the moment we do something to them; they participate in our early childhood projects. They live, speak, gesture, and call to us. (Kind, 2014, p. 865 of this issue)

This special issue of the International Journal of Child, Youth and Family Studies (IJCYFS) focuses on non-traditional approaches to materiality in relation to learning in early childhood education. The articles emerged, in large part, from a three-year study funded by the Social Sciences and Humanities Research Council of Canada (SSHRC), entitled Encounters with Materials in Early Education, through which the editors conducted a visual ethnography study in two early childhood centres in Western Canada. That research provoked interest in exploring more broadly how notions of materiality are taken up in different contexts.

Laurie Kocher, Ph.D. is an instructor and coordinator in the Early Childhood Education faculty at Douglas College, 1250 Pinetree Way, Coquitlam, British Columbia, Canada, V3B 7X3. E-mail: kocherl@douglascollege.ca

Veronica Pacini-Ketchabaw, Ph.D. is a Professor in the School of Child and Youth Care at the University of Victoria, P.O. Box 1700, STN CSC, Victoria, British Columbia, Canada, V8W 2Y2. E-mail: vpacinik@uvic.ca

Sylvia Kind, Ph.D. is an instructor and atelierista in the Department of Early Childhood Care and Education at Capilano University, 2055 Purcell Way, North Vancouver British Columbia Canada, V7J 3H5, e-mail: skind@capilanou.ca 
International Journal of Child, Youth, and Family Studies (2014): 5(4.2) 718-721

A primary goal of the Encounters with Materials project was to engage in an artbased collaborative inquiry to broaden understandings of the role that materials play in early childhood classrooms. Thinking with materials provokes different ways of thinking about early education and about how materials and young children live entangled lives in classrooms, transforming each other through various encounters. We have strived to reassemble early education spaces as vibrant social-ecological environments where humans and nonhumans are always in relation.

Materials, objects, and physical (non-human) elements have been important components of early childhood educational practices since programs for young children were developed. This materiality, however, has been invisible and under-theorized when thinking about learning. Central questions, which permeate all of the articles in this special issue, are: What are materials capable of in the early childhood classroom? How does the relationality of materials with the social, cultural, and discursive aspects reconceptualize learning in early childhood education? What if the human role in shaping materials is not as central as we believe? What if materials shape us as much as we shape them? How might we experience materials differently if we saw them as joint participants in our interactions with them? What happens when we choose to see materials, not as lifeless objects, but as events? How might a shift in perspective on materiality - including our own materiality - change the ways we interact with materials, with young children, and with other educators? And how might such shifts in perspective change the nature of our engagement with society and the environment?

\section{Overview of the Special Issue}

This special issue, then, is comprised of nine articles that take up such questions. Contributions include five theoretically-based, academic articles, combined with four essays that embody the voices of practitioners (we have called these "Ideas from the Field"), plus one book review. The practitioners, authors in the "Ideas from the Field" section, were invited by the editors to add their perspectives to this collegial conversation about materiality. Most articles are from Western Canada, but there is also a submission from Belgium. The contributions herein address materiality from a variety of perspectives: historical, pedagogical, critical, and artistic. Materials are understood not as static substances passively awaiting our signification; they are agential, participatory, active. As such, the focus throughout these articles is the performativity of materials, what materials are capable of.

\section{The Articles}

Philippe Noens and Stefan Ramaekers, with their contribution The Family as a "Gathering": How the Life of an Object Makes a Family, seek to develop a pedagogical answer to the question: what is it that constitutes a family? In their research they do not start from a substantial definition of the family; rather, they shift from a structural and institutional perspective on what the family is (or should be) to concrete socio-material practices that actually make a family. They see the family as a gathering of some sort where people are actively gathered around some-thing or some-one. In this article, they 
International Journal of Child, Youth, and Family Studies (2014): 5(4.2) 718-721

show how the family is "made" when inhabitants of a house are being gathered around the "life" of some object.

In contemporary early childhood contexts, children's photography is often seen as a democratic practice that incorporates children's photographs as representations of children's inner experiences of thinking, feeling, and learning. In Rethinking Photography as Event, Kim Ainsworth outlines tensions arising from photography inquiries that took place within a Canadian preschool setting. Within the context of early childhood education practice, anthropocentric, representational views of photography and childcentred practice are critiqued and contrasted with a relational materialist stance.

Vanessa Clark, Veronica Pacini-Ketchabaw, and B. Denise Hodgins think with the specificities of paint to tell stories about entanglements of settler colonialism and paint and painting in early childhood art education in their article, Thinking with Paint: Troubling Settler Colonialisms Through Early Childhood Art Pedagogies. They essay a messy, nonlinear picture of their work with children through a process of storytelling. Taking inspiration from contemporary artists and from antiracist and Indigenous scholars they portray their attempts to respond to and stay with the trouble their stories bring forward, gesturing toward hope and decolonizing strategies.

In her article, Playing with Dolls: (Re)Storying Gendered Caring Pedagogies, B. Denise Hodgins shares ordinary classroom stories of child-doll encounters that occurred during a collaborative research study that explored how children, educators, and things emerge as gendered caring subjects within early childhood practices. The historical and current dominance of dolls in early childhood practices and their links to gender and care make dolls such a significant material to think-with. The article works to unstick early childhood pedagogies from individualist and child-centred pedagogies, and rethink the apolitical and developmental logics that underpin "doll early childhood pedagogies". Implications for caring pedagogies are considered, including the necessity for making visible the interconnectedness of gender and care, tracing how (particular) practices come to matter, and responding within the complexity of knotted webs of relationality.

Kathleen Kummen considers how mattering and meaning are mutually constituted in the production of knowledge in her article, When Matter in the Classroom Matters. Drawing on a research project with first-year early childhood education students in a university setting, Kummen argues that material-feminism offers a lens through which pedagogical practices can be reconceptualized as more than anthropocentric endeavours. Her research explores the processes that occurred when, together with a group of early childhood education students, they engaged with and in pedagogical narrations, attempting to make visible and disrupt the hegemonic images of children and childhood they recognized that they held.

\section{Ideas from the Field}

Materials are entangled within complex assemblages that are constantly in motion. Kelsey Wapenaar draws on the notion of an "event” being a time where relationships between bodies of materials and people come together in intersection, attending to the 
International Journal of Child, Youth, and Family Studies (2014): 5(4.2) 718-721

dialogue between materials and human bodies, in Entanglements of Time. This time of intra-actions becomes alive and entangled, moving beyond chronological time to a rhythm of multiple time flows. To bring a feeling of tangibility to this idea, the article explores a series of events from Kelsey's work as an educator at a childcare centre, as well as her work as an artist. Specific encounters from these experiences are woven as a narrative throughout the article, illustrating the idea of material as an event where materials play an active role in assemblages and act with a sense of agency.

Thinking also of entanglements, Adrienne Argent describes a collective of adults and very young children that spend their days together in constant partnership with objects that are also active participants. In Dogwood Room Entanglements, Adrienne invites us to understand curriculum as an entanglement of time, place, bodies, materials, and more. Curriculum is not situated outside the child; rather, the two become enmeshed, (re)acting and transforming each other.

Vanessa Clark and Narda Nelson represent a conversation between a group of educators with their contribution, Thinking with Paint and Water. Throughout the dialogue, the educators reflect on their year's work with paint and water, discussing themes of rethinking their practice, challenges and struggles associated with the project, and the importance of working together as a team. They discover that playing with the possibilities, engaging the boundaries and limits, and challenging taken-for-granted pedagogical lenses, all offer up new means by which early childhood educators, can move towards increasingly meaningful and transformative experiences in their work.

Hearkening back to the opening words presented here, materials live in the world in multiple ways. In her visual essay, Material Encounters, based on an exhibit arising from the SSHRC-funded project described above, Sylvia Kind presents the reader with images and text that demonstrate how materials can evoke memories, narrate stories, invite actions, and communicate meanings. Materials and objects create meeting places around which educators gather to investigate, negotiate, converse, and share. Materials are not immutable, passive, or lifeless until the moment we do something to them; they participate in our early childhood projects. They live, speak, gesture, and call to us.

Finally, Marion Selfridge reviews Nancy Lesko’s 2012 book, Act Your Age! A Cultural Construction of Adolescence.

\section{Conclusion}

What does it mean to think with things? How does each material evoke particular invitations and provocations? How does each material live differently among/with/between other things and among/with/between young children? How are materials implicated in a classroom's movements? Or in a family's movements? These questions and resulting ideas are threaded throughout this special collection of articles. 